\title{
Seasonal and altitudinal variations of soil arthropods in Abies nordmanniana subsp. bornmulleriana forests
}

\author{
Variaciones estacionales y altitudinales de artrópodos del suelo \\ en bosques de Abies nordmanniana subsp. bornmuelleriana
}

\author{
Ahmet Duyar ${ }^{a}$ and Ender Makineci ${ }^{\text {b* }}$ \\ ${ }^{a}$ Western Black Sea Forestry Research Institute, 14101, Bolu, Turkey. \\ *Corresponding author: ${ }^{b}$ Istanbul University, Faculty of Forestry, Soil Science and Ecology Department, 34473, \\ Bahcekoy, Sariyer, Istanbul, Turkey, emak@istanbul.edu.tr
}

\begin{abstract}
SUMMARY
Seasonal and altitudinal variations in the abundance and diversity of soil arthropods were investigated in a pure Abies nordmanniana subsp. bornmulleriana (Uludağ fir) forest ecosystem. Sample plots were set at three different altitudes $(1,200 \mathrm{~m}, 1,400 \mathrm{~m}$ and 1,550 m), and samplings were performed in four seasons in February, May, August and November in 2010. Soil properties varied significantly among the seasons; higher soil nitrogen $(\mathrm{N})$ and carbon $(\mathrm{C})$ concentrations were found in summer while $\mathrm{C} / \mathrm{N}$ ratio and $\mathrm{pH}$ were higher in autumn. Litter mass decreased from winter to summer; however, litter nitrogen concentration was inversely correlated with litter mass. Litter $\mathrm{C} / \mathrm{N}$, potassium and magnesium concentrations were different among the seasons although litter $\mathrm{pH}$, carbon, phosphorus and calcium concentrations did not show significant differences. Soil $\mathrm{pH}$, phosphorus, calcium and magnesium concentrations mainly showed a decreasing trend with altitude; however, soil nitrogen and carbon concentrations had a significantly increasing trend. Litter mass did not have any significant difference although litter $\mathrm{pH}$, calcium and magnesium concentrations showed a significantly decreasing trend with altitude. In total, 54,348 individual soil arthropods were counted, identified and classified from 144 litter and soil samples collected in the study. The arthropods that were identified belonged to 90 different taxa within six classes and 28 orders, which were significantly different depending on habitats (soil or litter), altitudes and seasons throughout the year.
\end{abstract}

Key words: abundance, Aladağ, CCA, litter, Uludağ fir.

\section{RESUMEN}

Las variaciones estacionales y de altitud en la abundancia y diversidad de artrópodos del suelo fueron investigadas en un ecosistema forestal puro de Abies nordmanniana subsp. bornmuelleriana (abeto Uludag). Se establecieron parcelas de muestreo en tres altitudes $(1.200,1.400$ y $1.550 \mathrm{~m})$ y se muestrearon en cuatro temporadas (febrero, mayo, agosto, noviembre, 2010). Las propiedades del suelo variaron significativamente entre las estaciones; en verano se encontraron en el suelo concentraciones superiores de nitrógeno y carbono, mientras que la relación $\mathrm{C} / \mathrm{N}$ y el pH fueron mayores en otoño. La masa del mantillo disminuyó de invierno a verano y su concentración de nitrógeno correlacionó inversamente con la masa. En el mantillo, la relación C/N y las concentraciones de potasio y magnesio fueron diferentes entre estaciones del año, pero el pH y las concentraciones carbono, fósforo y calcio no mostraron diferencias significativas. En el suelo, el pH y las concentraciones de fósforo, calcio y magnesio mostraron tendencia decreciente con la altitud; sin embargo, las concentraciones de nitrógeno y carbono tuvieron una tendencia creciente significativa. La masa del mantillo no se diferenció significativamente, aunque el $\mathrm{pH}$ y las concentraciones de calcio y magnesio mostraron tendencia significativa a la baja con la altitud. Se contabilizaron 54.348 individuos de artrópodos del suelo, identificados y clasificados desde 144 muestras de mantillo y suelo. Los artrópodos identificados pertenecían a 90 taxones dentro de seis clases y 28 órdenes, que fueron significativamente diferentes en función de los hábitats (suelo o mantillo), altitudes y estaciones a lo largo del año.

Palabras clave: abundancia, Aladag, CCA, mantillo, abeto de Uludag.

\section{INTRODUCTION}

Soil arthropods can be used as bio-indicators in soil. Determining the constancy and variability of arthropod communities is very important in order to establish their predictability power for ecosystem processes. The significance of arthropods for ecosystem functions and soil has been determined regarding their biodiversity and abun- dance. Body sizes, forms and some organs of the soil arthropods allow them to live in various layers and depths of the soil (Razo-González et al. 2014). Arthropods can live on the forest floor, in the pores of litter and soil. Physiographic factors such as altitude, topography, aspect and slope; climatic variables including temperature, humidity and precipitation; site characteristics, habitat changes, forest floor and soil nutrients are important factors that may 
affect the abundance and diversity of arthropods (Townsend et al. 2008).

Forest soil and litter covering up the mineral soil represent the most important sources of biological diversity, and harbor a diversity of animals of varying sizes from protozoa to nematode and from microscopic acarina to small mammalian decomposers, except bacteria and fungi. In the soil ecosystem, the food chain containing arthropods is the basic linkage for food web, and it also includes macro fauna. All of these animals are heteropagus living at various trophic levels. Arthropods within the soil fauna play important roles in ecosystem processes such as litter decomposition, control of decomposers, nutrient cycling and contribution to biodiversity (Faber and van Wensem 2012). Besides their other fundamental functions, they are favorable soil quality regulators; furthermore, they are important for sustainable forest management (Sackett et al. 2010).

Ecological differences such as temperature and moisture regulate the life cycle of arthropods. Community structure and abundance of soil arthropods in a site may show seasonal variations; in particular, they are significantly affected by conditions such as the formation of different soil microclimates; alterations in the resource availability and changes in the food web (Logan et al. 2006). The climatic changes can occur in a wide range depending on the altitude, lead to alterations in the community structure of arthropods and can affect the activity rates of some species. However, the species that have tolerance to the changing climatic conditions depending on the altitude can be found at different altitudes, whereas the less tolerant species can only be found at a certain altitude (Pennings and Silliman 2005).

The aim of this study is to investigate the seasonal and altitudinal variations in the abundance and diversity of soil arthropods in the pure and full-canopy covered Abies nordmanniana subsp. bornmulleriana Mattf. (Uludağ fir) ecosystem that is an important forest tree species in Turkey. Therefore, the following research subjects are tested: (1) variations in the abundance and diversity of soil arthropods depending on the altitudinal zones and seasons, (2) relations between the properties of soil -litter and abundancediversity of soil arthropods depending on different seasons and altitudes throughout the one-year research period.

\section{METHODS}

Site description. The study was conducted in a pure $A$. nordmanniana subsp. bornmulleriana forest on Aladağ montainous mass extending in east-west direction in the south of Bolu Province-Turkey. The study site is located on the latitudes of $40^{\circ} 37^{\prime} 05^{\prime \prime} \mathrm{N}-40^{\circ} 39^{\prime} 36^{\prime \prime} \mathrm{N}$, longitudes of $31^{\circ} 35^{\prime} 33^{\prime \prime}$ E- $31^{\circ} 37^{\prime} 40^{\prime \prime} \mathrm{E}$, and altitudes from 1,200 to $1,550 \mathrm{~m}$. The overall mean stand characteristics of the sample plots are as follows: tree density $=500$ tree ha $^{-1}$, tree height $=19.8 \mathrm{~m}$, basal area $=53.6 \mathrm{~m}^{-2} \mathrm{ha}^{-1}$ and tree diameter at breast height $=34.3 \mathrm{~cm}($ Duyar 2014).
The parent material of the study site is andesite and the soil type is Luvisol. Average soil bulk density $(<2 \mathrm{~mm})$ is $474 \mathrm{~g} \mathrm{~L}^{-1}$ in the top soil $(0-5 \mathrm{~cm})$. The clay content of soil ranges from $18 \%$ to $24 \%$, while the soil reaction is 5.4$6.0 \mathrm{pH}$ changing at the different altitudes (Duyar 2014).

Mean annual precipitation is $555 \mathrm{~mm}$, and mean annual temperature is $10.5^{\circ} \mathrm{C}$, the hottest $\left(>16^{\circ} \mathrm{C}\right)$ period is between the $6^{\text {th }}$ and $9^{\text {th }}$ months. Similarly, precipitation is minimum between the $7^{\text {th }}$ and $9^{\text {th }}$ months according to the long-term (1960-2012) measured data of Bolu meteorology station (Duyar 2014).

Sampling and sampling design. Nine sample plots $(20 \times 20 \mathrm{~m})$ were selected in total in three replicates at three different altitudes $(1,200 \mathrm{~m}, 1,400 \mathrm{~m}$ and 1,550 m). These altitudinal zones were selected by taking account of a former research of Kantarc1 (1979), conducted in the same study area. Samplings were performed in four seasons in February, May, August and November in 2010. Two sampling sets were taken from each sample plot in each sampling time. Each sampling set contained as follows; one litter and one soil sample for analysis, one core sample to determine the soil moisture, one litter and one soil sample via steel soil corers for micro arthropods. In each sampling, 18 sampling sets were taken in two occasions from a total of nine sample plots; thus, 72 samples in total were collected throughout the research period. Soil temperatures were recorded by steel-tipped digital soil thermometer at five $\mathrm{cm}$ depth in each sampling period. Soil moisture was determined by wet and dry weight difference after dried at $105^{\circ} \mathrm{C}$ for $24 \mathrm{~h}$.

Sampling of arthropods from litter and soil. For sampling of arthropods in the field, steel cylinders with a diameter of $5 \mathrm{~cm}$ were used for undisturbed litter and soil samples. Litter samples were taken by pressing the steel cylinder in a vertical position down to the mineral soil level at the same points, while the soil samples were also taken from the mineral soils at a depth of $0-5 \mathrm{~cm}$ (Coleman et al. 2004).

Litter and soil samples for chemical analyses. Litter samples were taken from quadrats $(20 \times 20 \mathrm{~cm})$ at every sampling point by collecting the entire litter on the mineral soil surface at the same sampling point, soil samples were also taken from the mineral soils at a depth of $0-5 \mathrm{~cm}$. For other analyses, extra soil samples were taken from the same locations.

Extraction of the arthropods from the litter and soil samples. Samples in the steel cylinders were placed in Tullgren funnels to extract the arthropods; the samples were kept under 25-watt light bulbs providing heat for six days. Consequently, using the natural channels, arthropods gathered in the sample container contained $70 \%$ ethyl alcohol and $2 \%$ glycerin (Coleman et al. 2004).

Litter and soil analyses. Litter mass was determined by weighing the dried samples up to the constant weight at $65^{\circ} \mathrm{C}$. Carbon $(\mathrm{C})$ and nitrogen $(\mathrm{N})$ analyses were performed by 
the dry combustion method with $\mathrm{CN}$ analyzer (Leco Truspec 2000). The distribution of the soil particle size was determined by the Bouyoucos hydrometer method. International soil texture triangle was used to classify the soil texture. Soil acidity $(\mathrm{pH})(1: 2.5 \mathrm{soil} /$ water ratio) and litter reaction (1:10 litter/water ratio) were measured using a glass electrode digital $\mathrm{pH}$ meter. Phosphorus $(\mathrm{P})$ was determined in Spectronic 20D colorimeter. Soil samples were prepared by the ammonium acetate method for potassium (K), calcium (Ca) and magnesium $(\mathrm{Mg})$. Litter samples were prepared by wet digestion using nitric-perchloric acid. In the prepared filtrates, potassium concentration was determined using flame photometry, while calcium and magnesium were measured by atomic absorption spectrometer (Duyar 2014).

Identification and classification of the arthropods. Since the arthropods are macroscopic organisms, not easily visible, we used stereo binocular microscope (Leica S8 APO) to identify, classify and count them. Classification was performed at suborder and family level based on the functional groups. However, rare taxa were assessed at order or class level. Identification keys were used for the classification of arthropods (Duyar 2014).
Statistical analyses. The number of arthropods in the extracted samples was counted and they were determined as individuals in a square meter $\left(\mathrm{m}^{-2}\right)$. Correlations among the variables were evaluated statistically $(P<0.05)$ through the correlation analysis. The differences among the variables due to the independent variables such as season and altitude were compared through the analyses of variance (ANOVA). Significant differences $(P<0.05)$ in ANOVA were found with Duncan test. The canonical correspondence analysis (CCA) using the ordination techniques was performed to reveal the variations in arthropods due to the investigated variables.

\section{RESULTS}

Seasonal and altitudinal changes in the investigated characteristics. Soil $\mathrm{pH}$, nitrogen and carbon/nitrogen ratio $(\mathrm{C} / \mathrm{N})$ were significantly different across seasons. Soil nitrogen and carbon concentrations were particularly higher in summer while higher $\mathrm{C} / \mathrm{N}$ ratio and $\mathrm{pH}$ were in autumn. Investigated soil chemical properties (carbon, phosphorus, potassium, calcium and magnesium were not significantly different among seasons (table 1).

Table 1. Seasonal changes of soil properties and litter characteristics.

Cambios estacionales de las características del suelo y mantillo.

\begin{tabular}{lcccccl}
\hline Properties/Characteristics & Winter & Spring & Summer & Autumn & Mean \pm Sd. & $P$ \\
\hline Temperature $\left({ }^{\circ} \mathrm{C}\right)$ & \multicolumn{7}{c}{ Soil } & $1.5 \mathrm{a}$ & $7.0 \mathrm{~b}$ & $16.2 \mathrm{c}$ & $7.7 \mathrm{~b}$ & $8.1 \pm 5.4$ & $0.0001^{* *}$ \\
Moisture (\%) & $53 \mathrm{c}$ & $41 \mathrm{ab}$ & $36 \mathrm{a}$ & $45 \mathrm{~b}$ & $44 \pm 12$ & $0.0001^{* *}$ \\
$\mathrm{pH}$ & $5.5 \mathrm{a}$ & $5.7 \mathrm{a}$ & $5.8 \mathrm{ab}$ & $6.1 \mathrm{~b}$ & $5.8 \pm 0.5$ & $0.0040^{* *}$ \\
$\mathrm{~N}(\%)$ & $0.79 \mathrm{ab}$ & $0.82 \mathrm{~b}$ & $0.90 \mathrm{~b}$ & $0.68 \mathrm{a}$ & $0.8 \pm 0.2$ & $0.0040^{* *}$ \\
$\mathrm{C}(\%)$ & $9.6 \mathrm{ab}$ & $9.1 \mathrm{a}$ & $11.2 \mathrm{~b}$ & $9.5 \mathrm{ab}$ & $9.9 \pm 2.9$ & 0.1430 \\
$\mathrm{C} / \mathrm{N}$ & $11.9 \mathrm{~b}$ & $10.7 \mathrm{a}$ & $12.4 \mathrm{~b}$ & $13.9 \mathrm{c}$ & $12.2 \pm 1.9$ & $0.0001^{* *}$ \\
$\mathrm{P}\left(\mathrm{mg} \mathrm{kg}^{-1}\right)$ & $46 \mathrm{a}$ & $43 \mathrm{a}$ & $44 \mathrm{a}$ & $41 \mathrm{a}$ & $44 \pm 25$ & 0.9570 \\
$\mathrm{~K}\left(\mathrm{mg} \mathrm{kg}^{-1}\right)$ & $426 \mathrm{a}$ & $402 \mathrm{a}$ & $395 \mathrm{a}$ & $374 \mathrm{a}$ & $399 \pm 156$ & 0.8050 \\
$\mathrm{Ca}\left(\mathrm{mg} \mathrm{kg}^{-1}\right)$ & $3,890 \mathrm{a}$ & $4,122 \mathrm{a}$ & $4,415 \mathrm{a}$ & $4,127 \mathrm{a}$ & $4,138 \pm 1,062$ & 0.5390 \\
$\mathrm{Mg}\left(\mathrm{mg} \mathrm{kg}^{-1}\right)$ & $266 \mathrm{a}$ & $253 \mathrm{a}$ & $265 \mathrm{a}$ & $246 \mathrm{a}$ & $258 \pm 59$ & 0.6940 \\
\hline & & & $\mathrm{Litter}$ & & & \\
\hline $\mathrm{Mass}\left(\mathrm{g} \mathrm{m}^{-2}\right)$ & $6,172 \mathrm{c}$ & $5,182 \mathrm{~b}$ & $3,519 \mathrm{a}$ & $3,843 \mathrm{a}$ & $4,679 \pm 1,676$ & $0.0001^{* *}$ \\
$\mathrm{pH}$ & $6.0 \mathrm{a}$ & $5.8 \mathrm{a}$ & $6.1 \mathrm{a}$ & $6.1 \mathrm{a}$ & $6.0 \pm 0.4$ & 0.1390 \\
$\mathrm{~N}(\%)$ & $0.97 \mathrm{a}$ & $1.22 \mathrm{~b}$ & $1.45 \mathrm{~b}$ & $1.30 \mathrm{~b}$ & $1.23 \pm 0.4$ & $0.0001^{* *}$ \\
$\mathrm{C}(\%)$ & $30.6 \mathrm{a}$ & $30.0 \mathrm{a}$ & $33.0 \mathrm{a}$ & $30.7 \mathrm{a}$ & $31.1 \pm 5.8$ & 0.4370 \\
$\mathrm{C} / \mathrm{N}$ & $35.0 \mathrm{~b}$ & $26.3 \mathrm{a}$ & $22.9 \mathrm{a}$ & $23.9 \mathrm{a}$ & $27 \pm 8.3$ & $0.0001^{* *}$ \\
$\mathrm{P}\left(\mathrm{mg} \mathrm{kg}^{-1}\right)$ & $922 \mathrm{a}$ & $997 \mathrm{a}$ & $992 \mathrm{a}$ & $917 \mathrm{a}$ & $957 \pm 185$ & 0.4020 \\
$\mathrm{~K}\left(\mathrm{mg} \mathrm{kg}^{-1}\right)$ & $1,868 \mathrm{~b}$ & $1,584 \mathrm{a}$ & $1,906 \mathrm{~b}$ & $2,011 \mathrm{~b}$ & $1,842 \pm 390$ & $0.0060^{* *}$ \\
$\mathrm{Ca}\left(\mathrm{mg} \mathrm{kg}^{-1}\right)$ & $13,365 \mathrm{a}$ & $12,630 \mathrm{a}$ & $15,282 \mathrm{a}$ & $14,416 \mathrm{a}$ & $13,923 \pm 6,565$ & 0.6450 \\
$\mathrm{Mg}\left(\mathrm{mg} \mathrm{kg}^{-1}\right)$ & $2,095 \mathrm{~b}$ & $1,922 \mathrm{ab}$ & $1,752 \mathrm{a}$ & $1,774 \mathrm{a}$ & $1,886 \pm 323$ & $0.0030^{* *}$ \\
\hline
\end{tabular}

Sd: standard deviation, means within rows following by the same letter are not statistically different at 0.05 significance level in Duncan post hoc test. ** $P$-values are significant $(P<0.01)$. 
Litter mass was significantly higher in winter after litter fall in autumn while it decreased in summer season. Litter nitrogen concentration was inversely correlated with litter mass. Litter $\mathrm{C} / \mathrm{N}$ ratio, potassium and magnesium concentrations varied across the seasons although litter $\mathrm{pH}$, carbon, phosphorus and calcium concentrations did not have any significant differences (table 1).

Soil temperature, $\mathrm{C} / \mathrm{N}$ ratio, calcium and potassium did not have any significant altitudinal differences. Soil moisture at the altitude of 1,200 $\mathrm{m}$ was significantly lower than those presented by the other altitudes. General soil texture was loamy-clay; however, soil particle sizes were significantly $(P<0.01)$ different across the altitudes with an increasing trend in clay ratios from $1,200 \mathrm{~m}(18 \%)$ to $1,550 \mathrm{~m}(24 \%)$. Soil $\mathrm{pH}$, phosphorus, calcium, and magnesium concentrations mainly showed a decreasing trend, whereas soil nitrogen and carbon ratios had a significantly $(P=0.0001)$ increasing trend with altitude (table 2$)$.

Litter $\mathrm{pH}$, calcium and magnesium concentrations had a significantly decreasing trend with altitude, although other litter characteristics did not show significant altitudinal differences (table 2).

Relations between arthropods'abundance and soil - litter characteristics. According to CCA, the explanation rates of axes for the variance in taxa-soil properties were cumulatively determined as: first axis $=34.0 \%$, second axis $=$ $57.5 \%$, third axis $=73.9 \%$ and fourth axis $=84.9 \%$. Ordination graph is presented in figure $1 \mathrm{~A}$, demonstrating the correlation between soil properties and abundance of arthropods. Soil temperature was positively correlated with Tomoceridae, Isotomidae and Diplura taxa and negatively

Table 2. Altitudinal changes of soil properties and litter characteristics.

Cambios altitudinales de las características del suelo y mantillo.

\begin{tabular}{|c|c|c|c|c|c|}
\hline Properties/ Characteristics & $1,200 \mathrm{~m}$ & $1,400 \mathrm{~m}$ & $1,550 \mathrm{~m}$ & Mean \pm Sd. & $P$ \\
\hline \multicolumn{6}{|c|}{ Soil } \\
\hline Temperature $\left({ }^{\circ} \mathrm{C}\right)$ & $9.5 \mathrm{a}$ & $8.1 \mathrm{a}$ & $7.4 \mathrm{a}$ & $8.3 \pm 5.4$ & 0.3110 \\
\hline Moisture (\%) & $35 \mathrm{a}$ & $46 \mathrm{~b}$ & $51 \mathrm{~b}$ & $44 \pm 12$ & $0.0001 * *$ \\
\hline Sand (\%) & $60 \mathrm{~b}$ & $54 \mathrm{a}$ & $58 \mathrm{~b}$ & $58 \pm 6$ & $0.0010^{* *}$ \\
\hline Silt (\%) & $22 \mathrm{~b}$ & $24 \mathrm{~b}$ & $18 \mathrm{a}$ & $21 \pm 4$ & $0.0001 * *$ \\
\hline Clay (\%) & $18 \mathrm{a}$ & $22 \mathrm{~b}$ & $24 \mathrm{~b}$ & $21 \pm 4$ & $0.0001 * *$ \\
\hline $\mathrm{pH}$ & $6.0 \mathrm{~b}$ & $5.9 \mathrm{~b}$ & $5.4 \mathrm{a}$ & $5.8 \pm 0.5$ & $0.0001 * *$ \\
\hline $\mathrm{N}(\%)$ & $0.69 \mathrm{a}$ & $0.76 \mathrm{a}$ & $0.94 \mathrm{~b}$ & $0.8 \pm 0.2$ & $0.0001 * *$ \\
\hline $\mathrm{C}(\%)$ & $8.6 \mathrm{a}$ & $9.1 \mathrm{a}$ & $11.9 \mathrm{~b}$ & $9.9 \pm 2.9$ & $0.0001 * *$ \\
\hline $\mathrm{C} / \mathrm{N}$ & $12.2 \mathrm{a}$ & $11.7 \mathrm{a}$ & $12.8 \mathrm{a}$ & $12.2 \pm 1.9$ & 0.1390 \\
\hline $\mathrm{P}\left(\mathrm{mg} \mathrm{kg}^{-1}\right)$ & $44 \mathrm{~b}$ & $65 \mathrm{c}$ & $22 \mathrm{a}$ & $44 \pm 25$ & $0.0001 * *$ \\
\hline $\mathrm{K}\left(\mathrm{mg} \mathrm{kg}^{-1}\right)$ & $440 \mathrm{a}$ & $350 \mathrm{a}$ & $408 \mathrm{a}$ & $399 \pm 156$ & 0.1270 \\
\hline $\mathrm{Ca}\left(\mathrm{mg} \mathrm{kg}^{-1}\right)$ & $4,332 \mathrm{a}$ & $4,253 \mathrm{a}$ & $3,830 \mathrm{a}$ & $4,138 \pm 1,062$ & 0.2150 \\
\hline $\mathrm{Mg}\left(\mathrm{mg} \mathrm{kg}^{-1}\right)$ & $291 \mathrm{~b}$ & $252 \mathrm{a}$ & $230 \mathrm{a}$ & $258 \pm 59$ & $0.0010^{* *}$ \\
\hline \multicolumn{6}{|c|}{ Litter } \\
\hline Mass $\left(\mathrm{g} \mathrm{m}^{-2}\right)$ & 4,665 a & $4,338 \mathrm{a}$ & 5,033 a & $4,679 \pm 1,676$ & 0.3610 \\
\hline $\mathrm{pH}$ & $6.4 \mathrm{c}$ & $5.9 \mathrm{~b}$ & $5.6 \mathrm{a}$ & $6 \pm 0.4$ & $0.0001 * *$ \\
\hline $\mathrm{N}(\%)$ & $1.31 \mathrm{a}$ & $1.17 \mathrm{a}$ & $1.21 \mathrm{a}$ & $1.23 \pm 0.4$ & 0.4250 \\
\hline $\mathrm{C}(\%)$ & $31.1 \mathrm{a}$ & 30.9 a & $31.1 \mathrm{a}$ & $31.1 \pm 5.8$ & 0.9970 \\
\hline $\mathrm{C} / \mathrm{N}$ & $24.4 \mathrm{a}$ & $28.1 \mathrm{a}$ & $28.6 \mathrm{a}$ & $27.0 \pm 8.3$ & 0.1610 \\
\hline $\mathrm{P}\left(\mathrm{mg} \mathrm{kg}^{-1}\right)$ & 902 a & $950 \mathrm{a}$ & $1,019 \mathrm{a}$ & $957 \pm 185$ & 0.0880 \\
\hline $\mathrm{K}\left(\mathrm{mg} \mathrm{kg}^{-1}\right)$ & $1,755 \mathrm{a}$ & $1,776 \mathrm{a}$ & $1,996 \mathrm{a}$ & $1,842 \pm 390$ & 0.0580 \\
\hline $\mathrm{Ca}\left(\mathrm{mg} \mathrm{kg}^{-1}\right)$ & $17,817 \mathrm{~b}$ & $15,101 \mathrm{~b}$ & 8,851 a & $13,923 \pm 6,565$ & $0.0001 * *$ \\
\hline $\mathrm{Mg}\left(\mathrm{mg} \mathrm{kg}^{-1}\right)$ & $2,090 \mathrm{c}$ & $1,938 \mathrm{~b}$ & $1,628 \mathrm{a}$ & $1,886 \pm 323$ & $0.0001 * *$ \\
\hline
\end{tabular}

$\mathrm{Sd}$ : standard deviation, means within rows following by the same letter are not statistically different at 0.05 significance level in Duncan post hoc test. ** $P$-values are significant $(P<0.01)$. 
A)
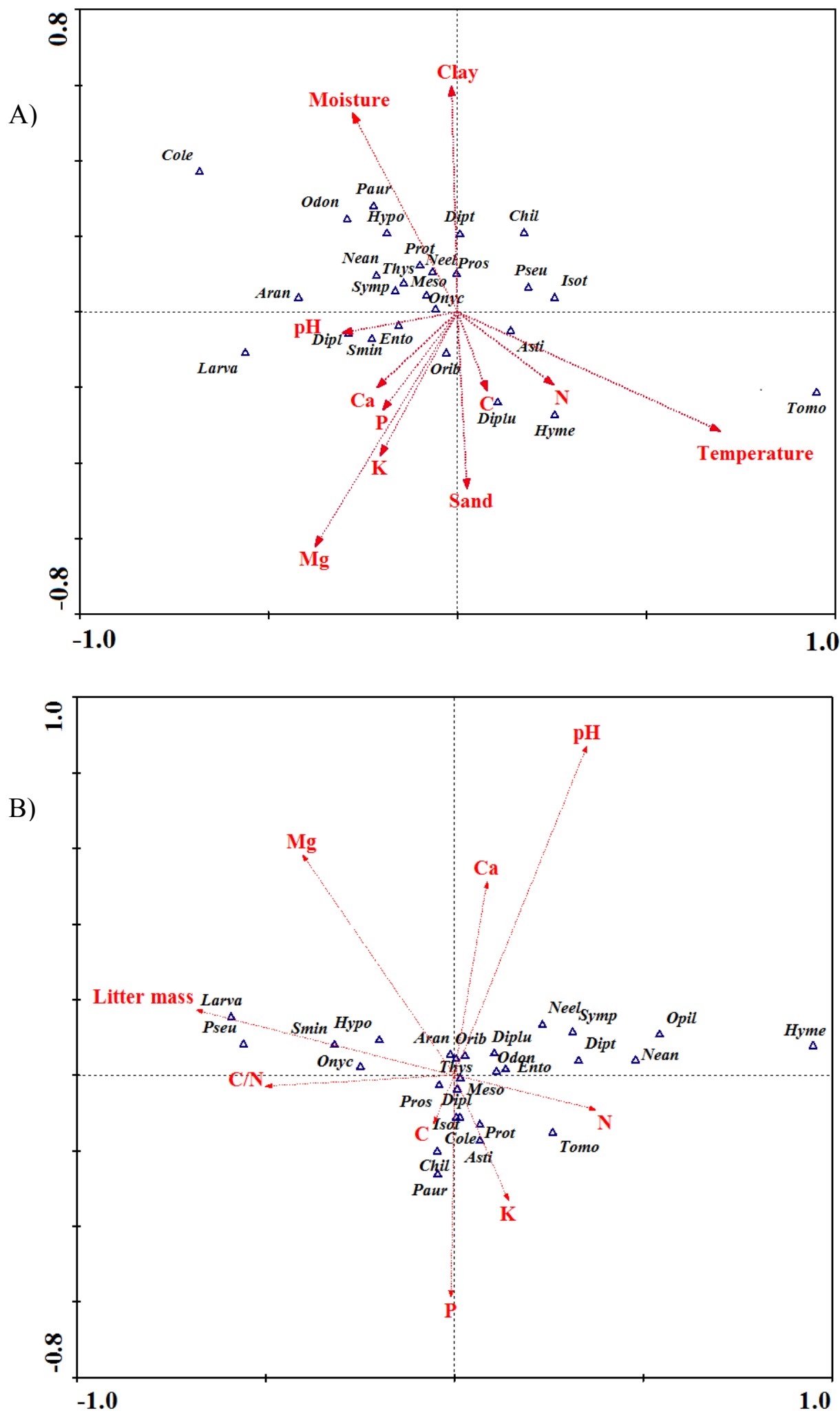

Figure 1. The CCA chart on the relationship of the arthropod with A) soil properties and B) litter characteristics.

Mapa del análisis de correspondencia canónica sobre las relaciones de los artrópodos con las características del suelo (A) y mantillo (B). 
correlated with Odontellidae taxon. Soil moisture was negatively correlated with Oribatida and Hymenoptera taxa and positively correlated with Odontellidae taxon. The soil sand ratio was in positive correlation with Oribatida taxon despite soil clay ratio was negatively correlated with Oribatida, Diplura and Hymenoptera taxa. Soil calcium and magnesium concentrations were in positive correlation with Oribatida taxon (figure 1A).

As a result of the CCA analysis, the explanation rates of axes for the variation in taxa due to litter characteristics were cumulatively determined as: first axis $=41.4 \%$, second axis $=65.6 \%$, third axis $=82.9 \%$ and fourth axis $=90.1 \%$. According to the relationships between arthropod abundance and litter characteristics; the litter mass was in positive correlation with insect larvae, Sminthuridae, Onychiuridae and Hypogastruridae, and it was negatively correlated with Tomoceridae, Neanurinae and Neelidae taxa. Litter nitrogen concentration and $\mathrm{pH}$ had a positive correlation with Hymenoptera, Entomobryidae, Symphyla and Diptera. Furthermore, litter phosphorus concentration was positively correlated with Astigmata and Pauropoda (figure 1B).

In total, 54,348 individual soil arthropods were counted, identified and classified from a total of 144 litter and soil samples throughout the study period. The identified arthropods belonged to 90 different taxa within six classes and 28 orders. The abundance of these taxa was significantly different across habitats, altitudes and seasons throughout the year. The annual mean individual number of arthropods per square meter was found to be 97,914 in soil, 175,822 in litter amounting to 273,736 in total (table 3).

Acarina and Collembola were the most abundant taxa in both soil and litter. The number of Acarina per square meter was 64,391 (66 \%) in soil and 118,013 (67\%) in litter; however, the number of Collembola was 26,827 (27\%) in soil and 54,086 (31\%) in litter (table 3).

In both soil and litter habitats, the abundance of the families in Acarina was in descending order in Oribatida, Prostigmata, Mesostigmata and Astigmata. Similarly, abundances of Collembola families were in descending order in Isotomidae and Odontellidae. Other arthropod groups were also found to be in various abundances and ratios (table 3).

As regards the seasonal variation in arthropods; soildwelling arthropods such as Mesostigmata, Oribatida, Prostigmata, Symphyla, insect larvae, Diptera, Onychiuridae, Entomobryidae and Isotomidae showed a significant $(P<0.05)$ seasonal difference. Mesostigmata, Oribatida, Onychiuridae and Isotomidae were more abundant in summer while Prositigmata was less abundant (20\%) especially in winter compared to other seasons. The abundance of soil-dwelling arthropods in litter such as Mesostigmata, Oribatida, Prostigmata, insect larvae, Onychiuridae, Odontellidae, Entomobryidae, Isotomidae, Tomoceridae, Neelidae, Sminthuridae and Protura taxa was also significantly different among seasons. Acarina families such as Mesostigmata, Oribatida and Prostigmata with Onychiuridae and Sminthuridae from Collembola were in minimum abundance in summer. On the other hand, an overall seasonal comparison revealed that the number of arthropods in soil (individuals $\mathrm{m}^{-2}$ ) was the maximum $(158,655)$ in summer and the lowest $(61,249)$ in winter, whereas the number of litter arthropods was the highest $(232,093)$ in autumn and the minimum $(137,452)$ in summer (table 3 ).

Regarding the variation in arthropods depending on altitude, only Diptera and Isotomidae taxa of soil-dwelling arthropods in mineral soil showed a significant difference. Furthermore, Oribatida, Isotomidae, Tomoceridae and Neelidae taxa in litter had significant altitudinal differences. As regards the variation in arthropods between soil and litter, only Tomoceridae showed a significant $(P=0.029)$ difference, all other arthropods in soil and litter except Tomoceridae had a similar distribution and did not have statistically significant differences. The altitudinal distribution of soil arthropods (individuals $\mathrm{m}^{-2}$ ) was the maximum at $1,550 \mathrm{~m}(101,797)$ and the minimum at $1,400 \mathrm{~m}$ $(93,717)$, although the abundance of litter arthropods was the highest at $1,200 \mathrm{~m}(190,793)$ and similar to the soil results, the lowest litter arthropod were detected at the altitude of $1,400 \mathrm{~m}(166,880)$ (table 4).

Regarding the preference of litter or soil habitats; Mesostigmata, Oribatida, Prostigmata, Symphyla, insect larvae, Onychiuridae, Isotomidae, Entomobryidae, Tomoceridae and Sminthuridae taxa showed significant differences depending on the seasons. Although the results in habitat preferences were not significantly different, mineral soil was more preferable for Pauropoda, Thysanoptera, Odontellidae, Neelida and Protura taxa, while the others preferred the litter (tables 3 and 4).

\section{DISCUSSION}

Seasonal and altitudinal changes in soil properties and litter characteristics. Soil moisture and temperature were significantly different among seasons. Soil moisture changed significantly whereas soil temperature did not change significantly across altitudes. Contrary to soil sand contents, soil clay contents showed a significantly increasing trend with altitude. Possibly because particle separation and clay formation are faster in the relatively more humid and more extreme climatic conditions that prevail at higher elevations and in the north aspect. Moreover, significantly changing clay content of soil at different altitudes may influence the altitudinal variations in soil moisture. Consistently with our results, Griffiths et al. (2009) demonstrated that soil moisture was significantly different depending on both altitude and season.

Litter characteristics that had significant differences across seasons included litter mass, $\mathrm{pH}$, nitrogen, $\mathrm{C} / \mathrm{N}$, potassium and magnesium. Furthermore, $\mathrm{pH}$, phosphorus, calcium and magnesium were the altitudinal litter characteristics that differed significantly. Significant seasonal changes in the soil properties were found to be in $\mathrm{pH}$, nitrogen and $\mathrm{C} / \mathrm{N}$; furthermore, soil properties such as sand, silt, clay, 


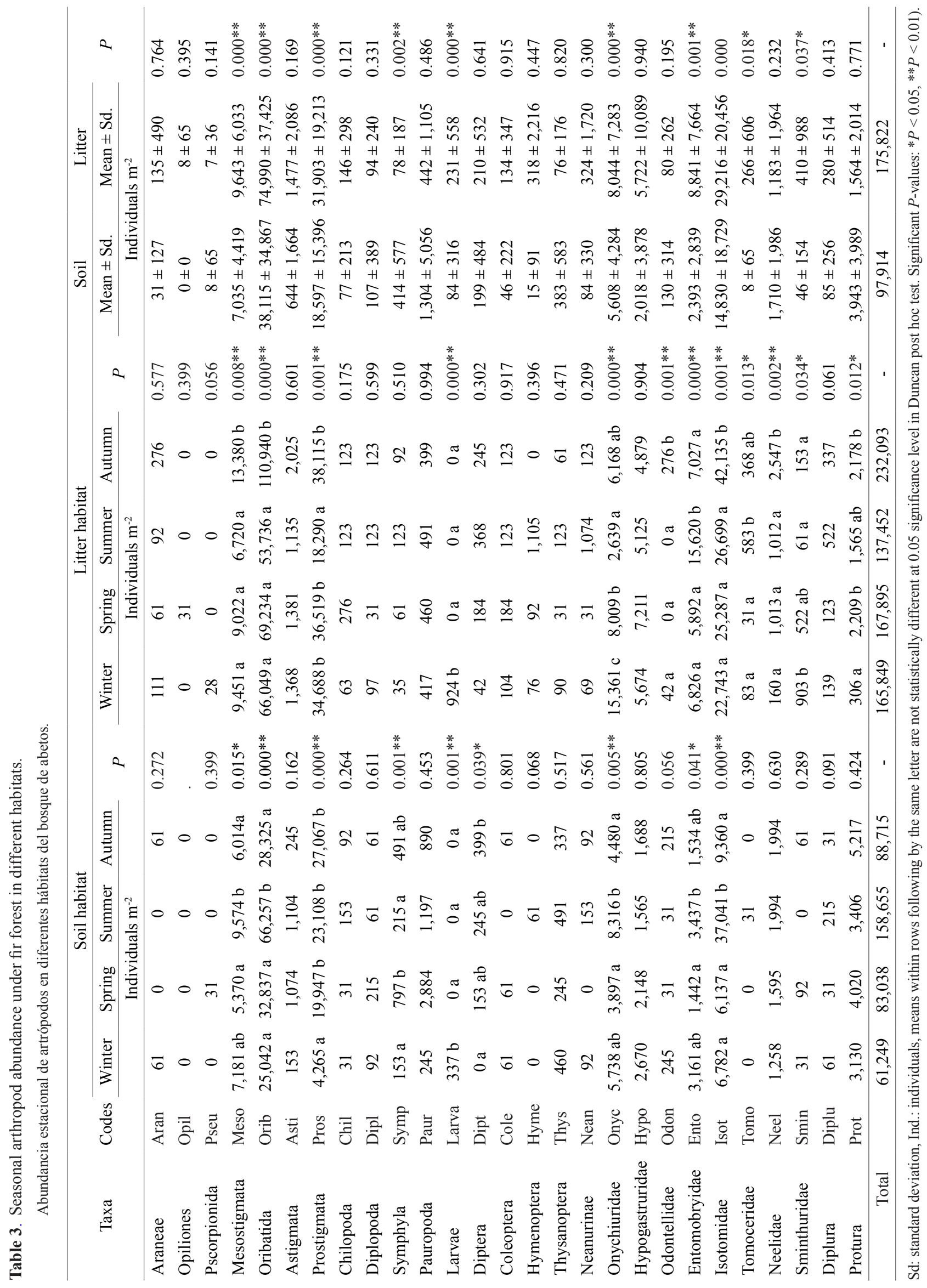




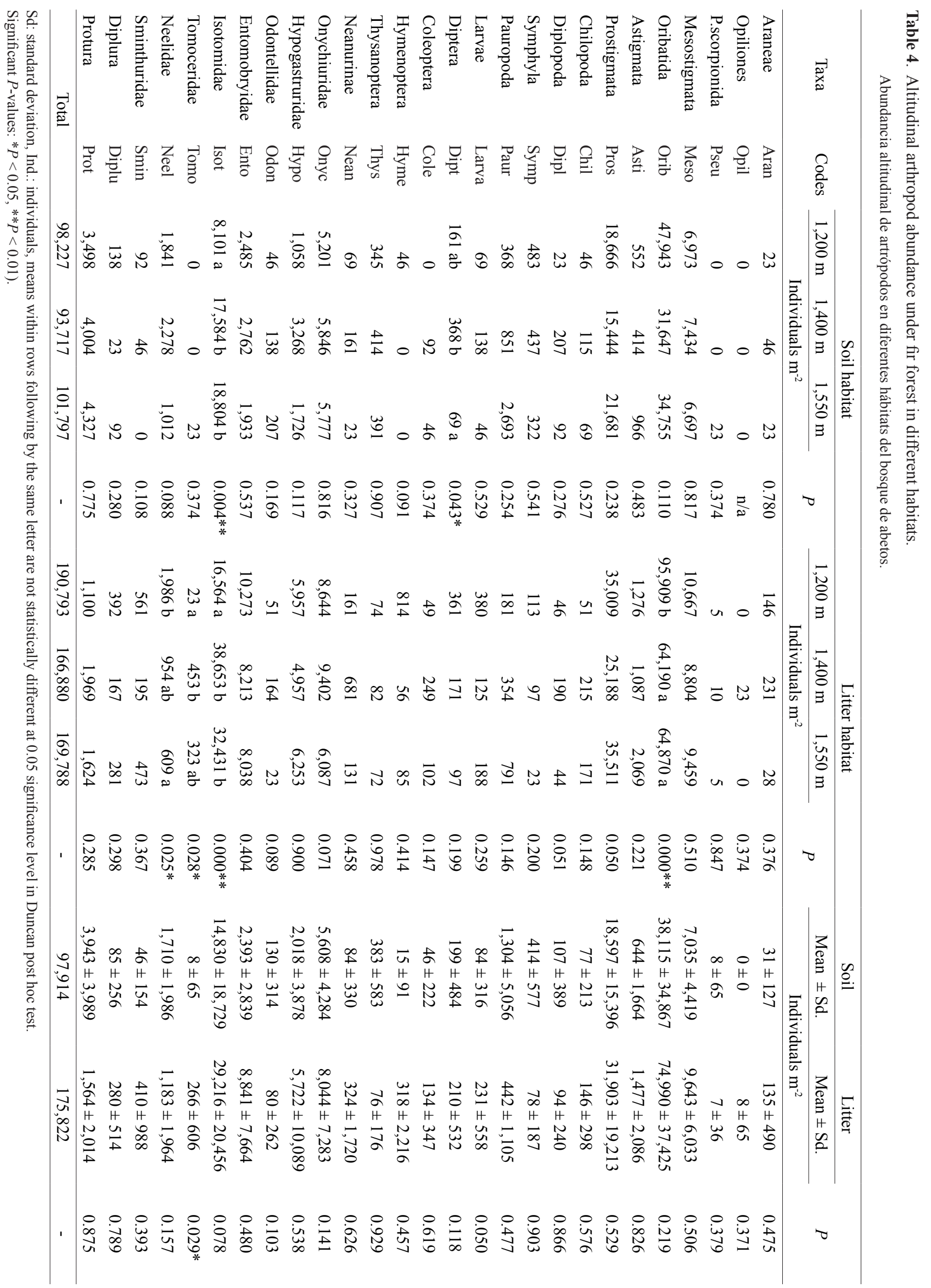


$\mathrm{pH}$, nitrogen, carbon, phosphorus, calcium and magnesium varied significantly across altitudes. Similarly, Zhao et al. (2014) reported that the distribution and the presence of soil and litter arthropods substantially depended on physical and chemical properties of soil and litter such as temperature, moisture, $\mathrm{pH}$, etc. in the temperate forest ecosystems.

The average annual litter mass was $4,679 \mathrm{~g} \mathrm{~m}^{-2}$. In different studies conducted in fir stands and supporting the results of this research, litter mass was found close to our value as $3850 \mathrm{~g} \mathrm{~m}^{-2}$ by Kantarc1 (1979) in the same region. Moreover, similar to our results, they did not find significant differences at different altitudes. On the other hand, contrary to our results, some researchers found that altitude had a significant effect on litter mass alterations (Güner 2006). There was a high variation among seasons regarding litter mass, which is consistent with our results; whereas several researches demonstrated different forest floorlitter changes in different seasons depending mostly on decomposition processes (Akburak and Makineci 2013).

Values of $\mathrm{pH}$ in both soil and litter are inversely related with altitude. In other words, the reactions of soil and litter are acidified with increasing altitude. Different results are reported in literature in this context. Güner (2006) stated that soil reaction changed significantly at different altitudes. Bolat (2011) found significant seasonal changes in $\mathrm{pH}$ of fir litter; however, no significant changes were found in soil $\mathrm{pH}$.

Litter and soil $\mathrm{C} / \mathrm{N}$ ratios were significantly different across seasons. Litter nitrogen concentrations did not change significantly depending on the season, whereas contrary to our results, significant seasonal variations were found in the litter nitrogen ratios in fir stands (Bolat 2011) and in oak stands (Çakır 2013). Similar to our findings at the altitude steps; Kidanemariam et al. (2012) found a significant variation in litter or soil nitrogen depending on the altitude; while contrary to these results, Güner (2006) did not detect a significant change.

In this study, soil phosphorus ratio had a negative correlation with altitude. The soil phosphorus concentrations found by Kidanemariam et al. (2012) in forest soils were very close to the ones revealed in this present study.

Although calcium concentrations of litter and soil were not significantly correlated with season, they had a significantly negative correlation with altitude. Similarly, Yilmaz (2004) found a significantly negative correlation between altitude and soil calcium concentration. Contrary to these results, Güner (2006) found no significant correlation between soil calcium and altitude but a significantly positive correlation between litter calcium and altitude.

In this present study, magnesium concentrations of litter and soil differed considerably between seasons and altitudes. Moreover, Kantarc1 (1979) highlighted a significant difference at the altitude steps in the same research area. Similar to our results, Yilmaz (2004), found a significantly negative correlation between the soil magnesium and altitude; in contrast, Güner (2006) reported a significantly positive correlation between altitude and litter magnesium.
Variation in arthropods. The distribution of arthropods in different habitats (soil and litter) showed significant variations. As mentioned above, differences in soil properties and litter characteristics due to altitudinal and seasonal changes were the possible causes of such variations. In this context, Antunes et al. (2008) stated that distribution of arthropods was not random, and strongly depended on chemical, physical and ecological conditions. Furthermore, they demonstrated that factors such as climatic, geomorphological, physical and chemical conditions in addition to the processes related to the distribution, growth and development of flora and fauna as well as the relationships between competition and predation were the main effects on the distribution of soil arthropods.

Litter mass and depth or structural features of micro habitats can influence the life cycle of arthropods. Many groups of arthropods are sensitive to the structure of litter; especially Araneae and Acarina are sensitive to litter features (Hansen 2000). In our study, Hypogastruridae, insect larvae, Onychiuridae and Sminthuridae taxa were positively correlated and Tomoceridae taxon was negatively correlated with litter mass.

Biological activities can only be initiated under the available temperature and moisture conditions. The temperature and moisture of soil have a major impact on the life of arthropods. Medianero et al. (2007) demonstrated that the rising temperature under the available moisture conditions increased the abundance of arthropods, and the water loss of both litter and soil due to the increased evaporation at higher temperatures decreased the abundance of arthropods. This may also be relevant for the interpretation of the results of the present study.

Soil sand content had a significantly positive correlation with taxa of Oribatida, Hymenoptera, and Diplura. On the other hand, soil clay content had a significantly positive correlation with Diptera and Prostigmata and negative correlation with Oribatida, Hymenoptera and Diplura. Sandy soil might be specifically preferred by saprophagous taxa because of its large porous structure for feeding and sheltering. Similarly, Gutiérrez-López et al. (2010) found that Isotomidae, Sminthuridae, Actinedida and Macropylina taxa had a positive correlation with clay and silt contents of soils; however, Poduromorpha and Entomobryidae taxa had a higher correlation with sand content and porosity of soil.

The reactions $(\mathrm{pH})$ of soil and litter and nutrients showed significant correlations with some of arthropod taxa. Phosphorus, potassium, nitrogen and sodium are important nutrients related to soil arthropod fauna (RazoGonzález et al. 2014). Furthermore, taxa that have welldeveloped external skeletons such as Oribatida contain high amounts of calcium compounds such as calcium carbonate, calcium oxalate and calcium phosphate in their external skeletons (Coleman et al. 2004). Oribatida and Coleoptera had significantly positive correlations with calcium and magnesium in our study. Gutiérrez-López et al. (2010) found a positive correlation between soil $\mathrm{pH}$ and 
Isotomidae, Sminthuridae, Actinedida and Macropylina taxa. On the other hand, Abbas (2012) demonstrated that the abundance of Collembola had a significantly negative correlation $(\mathrm{r}>-0.708)$ with soil $\mathrm{pH}$ in both the natural and degraded sites under monsoon climate. In the acid soil in coniferous forests, arthropods feeding on litter such as Collembola and Oribatida were the dominant groups. The addition of nutrients with nitrogen to the site directly influences microbial communities; therefore, it also causes an increase in the number of consumers of microbial bacteria and fungi such as Collembola and Acarina (Cole et al. 2008). Moreover, the diet of some macro-arthropods such as spiders and ants that are predators and omnivore largely depends on the presence of Collembola and mites, while their abundance may also increase (Halaj and Wise 2002).

In addition to the changing soil and litter characteristics, the changes in soil temperature or moisture arising from altitudinal and seasonal differences influence both some ecological characteristics and the life cycle of arthropods (Logan et al. 2006). Because of these alterations, the abundance and community structure of the arthropods in the environment also show seasonal and altitudinal changes. Acarina and Collembola taxa were the most affected arthropod groups. Significant changes in the distribution of soil arthropods due to the season are mainly controlled by the interactions between soil temperature and soil moisture. Arthropods living in the litter are more sensitive to seasonal changes than soil micro-arthropods and they can migrate into deeper soil layers in different seasons (Medianero et al. 2007). Abbas (2012) showed that the number of Collembola individuals was significantly different in seasons in the monsoon climate region while the cause of this was observed to be large-scale seasonal variations in soil temperature and moisture.

Önen and Koç (2011) reported that Oribatida and Mesostigmata taxa were observed to be the most abundant in the winter; however, Prostigmata and Astigmata taxa were the most abundant in spring. Similar to our results, they stated that the abundances of all taxa were the lowest in summer, possibly resulting from summer drought in the soil. The wide range of climatic changes due to altitude can alter the structure of the arthropod community and can affect the activity rate of specific species. Arthropods response to the changing environmental conditions due to altitude. In forestlands, local climate variations resulting from altitudinal changes lead to the taxa-specific variations. However, it is difficult to generalize all variations depending on the altitudinal differences. Due to rising seasonal temperature and declining soil moisture, some arthropod taxa migrated from the litter to the mineral soil in summer. The number of individuals was found to be the highest in soil and the lowest in litter. Similar to our findings, Önen and Koç (2011) reported that arthropods could migrate vertically into the soil layers due to the seasonal conditions in addition to the seasonal and altitudinal changes.

\section{CONCLUSIONS}

In conclusion, arthropods have different variations in abundance and diversity depending on the altitudinal and seasonal features. Besides, we have shown that abundance-diversity of soil arthropods were not random, and strongly depended on chemical and physical properties of soil and litter in different seasons and altitudes throughout the one-year research period. The local factors in the research area such as spatial variation in resource availability in different habitats (soil and litter) and microclimate may further influence the abundance and individuals of particular taxa. Moreover, the contribution of these organisms to the ecosystem processes may also vary depending on these alterations. However, the sampling was performed at each altitude in four seasons, and the study period was one year. A bigger number of samplings may give clearer results and repeated ongoing surveys would help clarifying the patterns.

\section{ACKNOWLEDGEMENTS}

This manuscript contains some results presented in Dissertation of Ahmet DUYAR under the supervision of Ender MAKINECI completed in 2014 at Istanbul University, Science Institute. This work was supported by Turkish General Directorate of Forestry, project number: 08.6301/2007-2010-2014.

\section{REFERENCES}

Abbas MJ. 2012. Seasonal diversity of Collembola assemblages in two different habitats of Aligarh. Indian Journal of Fundamental and Applied Life Sciences 2: 18-25.

Akburak S, E Makineci. 2013. Temporal changes of soil respiration under different tree species. Environmental Monitoring and Assessment 185: 3349-3358.

Antunes SC, R Pereira, JP Sousa, MC Santos, F Gonçalves. 2008. Spatial and temporal distribution of litter arthropods in different vegetation covers of Porto Santo Island (Madeira Archipelago, Portugal). European Journal of Soil Biology 44: 45-56.

Bolat I. 2011. Seasonal changes of microbial biomass carbon (Cmic), nitrogen (Nmic), phosphorus (Pmic) in top soil and forest floor in beech, fir and fir-beech stands. Dissertation. Science Institute, Bartın University. 397 p. (In Turkish with English Summary)

Cole L, SM Buckland, RD Bardgett. 2008. Influence of disturbance and nitrogen addition on plant and soil animal diversity in grassland. Soil Biology and Biochemistry 40(2): 505-514.

Coleman DC, DA Crossley, PF Hendrix. 2004. Fundamentals of soil ecology. London, UK. Academic Press. 386 p.

Çakır M. 2013. Seasonal changes of soil arthropods in beech and oak ecosystems and their effects on litter decomposition. Dissertation. Science Institute, Istanbul University. 137 p. (In Turkish with English Summary).

Duyar A. 2014. Seasonal variation of soil arthropods (Arthro- 
poda) in fir (Abies bornmulleriana Mattf.) ecosystems in Bolu-Aladag. Dissertation. Science Institute, Istanbul University. 165 p. (In Turkish with English Summary).

Faber JH, J van Wensem. 2012. Elaborations on the use of the ecosystem services concept for application in ecological risk assessment for soils. Science of the Total Environment 415: 3-8.

Griffiths RP, MD Madritch, AK Swanson. 2009. The effects of topography on forest soil characteristics in the Oregon Cascade Mountains (USA): Implications for the effects of climate change on soil properties. Forest Ecology and Management 257: 1-7.

Gutiérrez-López M, JB Jesús, D Trigo, R Fernández, M Novo, DJ Díaz-Cosín. 2010. Relationships among spatial distribution of soil microarthropods, earthworm species and soil properties. Pedobiología 53(6): 381-389.

Güner ŞT. 2006. Determination of growth-nutrition relationships of Scots pine (Pinus sylvestris ssp. hamata) forests at Turkmen Mountains (Eskișehir, Kütahya). Dissertation. Science Institute, Anadolu University. 298 p. (In Turkish with English Summary).

Halaj J, DH Wise. 2002. Impact of a detrital subsidy on trophic cascades in a terrestrial grazing food web. Ecology 83(11): 3141-3151.

Hansen RA. 2000. Effects of habitat complexity and composition on a diverse litter microarthropod assemblage. Ecology 81(4): 1120-1132.

Kantarcı MD. 1979. Aladağ kütlesinin (Bolu) kuzey aklanındaki Uludağ Göknarı ormanlarında yükselti-iklim kuşaklarına göre bazı ölü örtü ve toprak özelliklerinin analitik olarak araştırılması. İ.Ü.Yay.No.2634, Orman Fakültesi Yay. No.274, İstanbul. 220 p. (in Turkish).

Kidanemariam A, H Gebrekidan, T Mamo, K Kibret. 2012. Impact of altitude and land use type on some physical and chemical properties of acidic soils in Tsegede highlands, Nor- thern Ethiopia. Open Journal of Soil Science 2(03): 223.

Logan JD, W Wolesensky, A Joern. 2006. Temperature-dependent phenology and predation in arthropod systems. Ecological Modelling 196(3): 471-482.

Medianero E, G Castano-Meneses, A Tishechkin, Y Basset, H Barrios, F Odegaard, AR Cline, J Bail. 2007. Influence of local illumination and plant composition on the spatial and seasonal distribution of litter-dwelling arthropods in a tropical rainforest. Pedobiología 51(2): 131-145.

Önen Ö, K Koç. 2011. Seasonal and vertical distribution of Acarina fauna of grassland. Çankaya University-Journal of Science and Engineering 8(2): 277-289.

Pennings SC, BR Silliman. 2005. Linking biogeography and community ecology: latitudinal variation in plant-herbivore interaction strength. Ecology 86(9): 2310-2319.

Razo-González M, G Castaño-Meneses, A Callejas-Chavero, D Pérez-Velázquez, JG Palacios-Vargas. 2014. Temporal variations of soil arthropods community structure in El Pedregal de San Ángel Ecological Reserve, Mexico City, Mexico. Applied Soil Ecology 83: 88-94.

Sackett TE, AT Classen, NJ Sanders. 2010. Linking soil food web structure to above and belove-ground ecosystem processes: a meta-analysis. Oikos 119: 1984-1992.

Townsend AR, GP Asner, CC Cleveland. 2008. The biogeochemical heterogeneity of tropical forests. Trends in Ecology \& Evolution 23(8): 424-431.

Y1lmaz M, 2004. The effects of some site factors on growth of beech on pure oriental beech ecosystems at eastern Black Sea Section. Dissertation. Science Institute, Black Sea Technical University. 188 p. (In Turkish with English Summary).

Zhao HL, J Li, RT Liu, RL Zhou, H Qu, CC Pan. 2014. Effects of desertification on temporal and spatial distribution of soil macro-arthropods in Horqin sandy grassland, Inner Mongolia. Geoderma 223: 62-67. 
